\title{
COREESPONDEINCE.
}

THE LOESS AND THE EPOCH OF THE MAMMOTH.

SrR,-Non omnia possumus omnes is an old adage especially to be remembered in complex inquiries. May I crave permission therefore, as I am honestly bound to do, to correct two errors of fact into which I have been led by the authorities I have followed. I followed Mr. James Geikie (Prehistoric Europe, p. 87) in naming the Lemming as found in Brixlam Cavern. My friend Mr. Pengelly writes me that for Lemming ought to be writ Lagomys. This substitution does not of course affect the argument I used, except by strengthening it, since the Lagomys is more associated with grassy plains than the Lemming. Mr. Swanston in a courteous letter in the GEOI. Mag. for April corrects not so much me as Mr. Bell, whose paper I quoted. Here again, as he most fairly says, the correction does not in any way affect the induction I made. It is at the same time singular that the highest points at which marine shells have occurred in the surface-drifts of Britain should be on opposite sides of St. George's Channel nearly where it is narrowest, and where the water if rushing violently would be most throttled, and therefore rise to the greatest height.

I would next crave a small space in which to refer to a theory propounded by Mr. Searles Wood, F.G.S., in a recent Number of the Geotogrcal Magazine, and repeated by him in a recent number of the Journal of the Geological Society, in which he claims to account for the Loess in a new way, namely, by lateral movements of the ground under conditions such as exist in the Siberian tundras. I confess that I have read over the passages in which this theory is maintained with surprise. Mr. Searles Wood is such an experienced field geologist that it would have been dangerous to suggest that he has never seen or handled Loess. He himself, however, makes this confession (GEoL. MAG. Vol. IX. Second Series, p. 339). Only in this way can I explain the conclusion he has formulated. In the first place, he treats the Loess as being a mere form of loam, and identifies it with the Limon Hesbayen of the Belgian geologists. No doubt the two deposits are more or less synchronous, but without doubt they are very different in composition and texture, and require an entirely different explanation if we are to account for their oriurin. The first and most important feature of the Loess, which discriminates it at once from the loamy deposits and which requires a special explanation, is its being saturated with carbonate of lime. How does Mr. Wood's theory meet this at all ? The curious capillary structure of Loess is its second most remarkable feature. This is assuredly entirely at issue with lateral molecular movements such as Mr. Searles Wood suggests. The long fine tubes that permeate the Loess so thickly would be destroyed and its structure rendered completely homogeneous by the slightest movements such as he supposes. Again, such movements could only occur if at all in a pasty plastic mass, but the structure of Ioess is the antithesis of such a plastic condition. As Baron Richthofen says, "water which 
forms pools on loam enters into Loess as into a sponge, and percolates it without in the least converting it into a pulp or mud."

This at once answers Mr. Wood's notion, that when the ground is frozen to great depths the surface layers of Loess, when melted by the summer sun, would be converted into sludge. And this is essential to his theory ; for, as he says, where the material acted on is porous sand or gravel, the water arising from the summer melting of the surface layers would escape laterally without any displacement of the material itself. This is exactly the case with Loess, which is more porous than sand or gravel.

Again, how can Mr. Wood invoke the severely Arctic conditions his theory necessitates when he examines the Mammals, the Molluscs, and the Plants whose remains are found so widely distributed in the Loess? They bespeak comparatively temperate conditions when the Loess was deposited. Lastly, granting that these fundamental difficulties were overcome, it is assuredly unsafe to base such an induction as Mr. Wood makes upon a series of hypothetical data, as to the action of frost upon beds of soft material without, so far as I know, a single empirical test. We may as well claim the mirage for reality. Is not his method the very one he reprobates in the sentence about resorting to causes wholly supposititious, or only found to be in action to some very subordinate extent? It is in the domain of logic and geological induction, where we are equal, and not of geological observation, where we are not, that $I$ claim to meet Mr. Wood, and to show that his arguments as applied to the real Loess, and not to some hypothetical Loess, are incomprehensible.

I must, in conclusion, reply to my old friend Professor Dawkins. I am not going to discuss with him whether there be a special logic for Lawyers, and another for Professors, nor whether in the terribly wide inductions that Science must make nowadays, if it is to compass all the facts, it is prudent or wise to base arguments on our own observations only, or on the observations of all good men. These are matters upon which your readers will, I am sure, not agree with Mr. Dawkins. Let us turn from such small issues to one of real importance, namely, the range in time of the Mammoth. Professor Dawkins admits that I was right in saying he had changed his view on this subject. He claims to have done so because of fresh evidence. First he cites the Scotch caves. This reference is a mystery to me. I know of no Scotch caves containing Mammoth remains, and I should be obliged by a reference to them. Secondly, he refers to Dr. Falconer's opinion, but Dr. Falconer's opinion was before him when in 1869 he wrote as follows of the Pre-Glacial Mammals: "To this list Dr. Falconer would add the Mammoth; but a careful investigation into the evidence which was supposed to establish its Pre-Glacial age has convinced me that the inference was faulty. The specimens reported to come from the 'Forest Bed' are in every case mere waifs and strays thrown up by the sea between high- and low-water mark, or very possibly derived from the sands above the Boulder-clay. The remains dredged up from the bed of the sea, in the collection of Mr. Owles, establish the fact that a Post-glacial 
deposit containing Reindeer, Tichorhine Rhinoceros, and Mammoth exists off Yarmouth, which very probably was the source whence some of the drifted remains were ultimately derived" (Proc. Geol. Soc. 1869, p. 210). This is not all. Dr. Falconer-great authority as he was on the fossil Elephants-conld not claim the minute acquaintance with the "Forest Bed" possessed by Mr. Gunn, who was especially in my view when I referred to those best entitled to give an opinion on such a subject. Mr. Gunn persistently denied the presence of the Mammoth in the "Forest Bed," and Professor Adams, writing in 1872, says: "This view is still maintained by the Rev. J. Gunn, F.G.S., who has informed me that his latest experience gave him no cause to alter his views on that head" (British Fossil Elephants, p. 72). But Mr. Gunn is not alone. Mr. Clement Reid, who has worked so well in Eastern England, says, in "Nature," vol. xix.: "All the specimens said to come from the 'Forest Bed' have been dredged or picked up on the beach, and are of no value whatever. At Bacton, on the Norfolk coast, I dug out a jaw and three teeth of the Mammoth from a Post-Glacial deposit; if the denudation of the cliff had proceeded these teeth would have been found on the beach mixed with those of $E$. meridionalis. There appears to be one specimen, and only one, found in situ in the 'Forest Bed,' which can with any probability be referred to $E$. primigenius; this was found some years ago by Mr. Savin, of Cromer. It has not yet been satisfactorily determined, but from its peculiarity and the difference of opinion about it, it appears certainly not to be the ordinary form."

Professor Dawkins says that "the fact of the Mamrnoth being Pre-Glacial was accepted by the late Professor Leith Adams in his work on the Mammoth" (Pal. Soc.). This is a most extraordinary statement. The following are Professor Adams's very words :- - The evidence of the Mammoth having lived during Pre-Glacial times has not been established by the specimens from the coast of Norfolk, at all events as far as the instances hitherto recorded are concerned" (British Fossil Elephants, Pal. Soc. pp. 72 and 73).

Mr. E. T. Newton, who is also quoted against me, says expressly that "the only reliable specimens from the Forest Bed of the Elephas primigenius are in Mr. Savin's collection, and were obtained near Cromer. But it is important to observe that they differ from the typical E. primigenius" (Mem. Geol. Surv. p. 106).

I confess to feeling very much embarrassed when I found Professor Dawkins quoting autborities in support of a theory which they repudiate so plainly. This is certainly not "Mr. Howorth's way of disposing of evidence."

Mr. Dawkins refers in a vague way to a number of instances which have occurred since 1868 which have established in his view the Pre-Glacial age of the Mammoth. May I ask for a reference to these cases. I have made diligent search for them, but hitherto have only found the famous Northwich instance, which had such an extraordinary effect on my impulsive friend the great Troglodyte. In regard to this tooth, Professor Adams, one of the witnesses cited by Mr. Dawkins himself, says, "The latter piece of eridence is, however, 
like the others faulty, from the absence of direct proofs as to, 1st, the exact stratigraphical horizon; $2 \mathrm{nd}$, the age of the deposit; and, 3rd, the mode by which the information was obtained" (op. cit. p. 73). In addition, Mr. C. Reid (loc. cit.) and Mr. Horace B. Woodward (Grou. Mag. 1879, p. 235) both show very plainly that this Cheshire tooth is really valueless in the discussion. HenRY H. Howorth.

Derry Hoese, Eccles,

July 5 th, 1883.

\section{CHALK MASSES IN THE CROMER DRIFT.}

Sir,--Mr. Searles Wood gives Professor H. G. Seeley, writing in 1864, as an authority that the old Hythe Pinnacle of chalk figured by Sir Charles Lyell in his Elements, p. 129, is not chalk, "but only re-constructed chalky drift full of all sorts of rocks." As Lyell in a letter to Sir Charles Bunbury in 1864 states that it, "the grandest erratic in the world," had at that time "totally disappeared," it is difficult to understand how Prof. Seeley in the same year was justified in making such a statement. It is rather common now to assume that the late generation of geologists made incorrect observations, but I shall require better evidence before I can believe that Sir Charles could not, in common parlance, distinguish chalk from cheese-or say, "chalky drift full of all sorts of rocks."

But we will assume for the sake of argument that the pinnacle was of re-constructed chalk. What then becomes of Mr. Searles Wood's statement that "when the masses of re-constructed chalk were brought and sunk deep into the substance of the sea-bed, the whole of this county was submerged"?

Deep indeed they would have had to be sunk, as the pinnacle in question is shown reposing upon the "pan" immediately overlying the chalk, with its base imbedded in Till, and the whole npper part surrounded and covered with contorted drift. The boulder figured by me (p. 281, Q.J.G.S., 1882) is undoubtedly of real chalk, and it is not interstratified with the drift. It is also true that there are other included masses intermediate between chalk and chalky drift, but no hard and fast line in their mode of occurrence can be drawn between them. The phenomena are counected, as is well shown ${ }^{2}$ by Mr. H. B. Woodward in his description of the "disturbed chalk at Trowse."

To conclude this correspondence, I cannot accept hypothetical icesheets as an explanation of the disappearance of what otherwise, by Mr. Searles Wood's theory, we ought to find, and I think I have a right to complain that he has a habit, unintentional no doubt, of putting among his facts what are in reality only opinions or inferences from his own theories.

July $\bar{s} t h, 1883$.

${ }^{1}$ Life of Lyell, vol. ii. p. 441. Mr. Seeley speaks of pinnacles, whereas Sir Charles merely refers to one.

2 Memoir of the Geology of the Country about Norwich.

Erratum.-Geol. Mag. July, 1883, p. 332, line 7 from bottom of page for alternation read attenation. 